\title{
Europe's Galileo project gains ground
}

Long-troubled satellite-navigation system receives formal backing from European Commission president.

\section{BRUSSELS}

Europe is inching closer to realizing its farreaching plans for Earth-observing. Last week José Manuel Barroso, president of the European Commission (EC), publicly confirmed his support for the Galileo and GMES satellite-navigation and Earth-monitoring programmes.

"Without space applications we will not be able to observe and tackle climate change," Barroso told a European space conference held in Brussels on 15-16 October. "Without space research, our knowledge society will simply not come about."

Critics point out, however, that Galileo has been in the works for a decade and still does not have the first of 30 planned satellites in orbit.

Volker Liebig, director of Earth-observation programmes for the European Space Agency (ESA) in Frascati, Italy, said that Barroso's presence at the meeting was "a real sign of change". It is the first time that Barroso, who was re-elected in September for a second five-year term as president, has attended a meeting on Galileo and offered his support so publicly. "This is proof of the stronger and stronger involvement of the European Union [EU] in space policy," says Alain Bories, director for strategy at satellite manufacturer OHB Technology in Bremen, Germany. "This is good news."

Galileo, Europe's ambitious answer to the US Global Positioning System (GPS), is set to become operational in 2013. Its troubled past includes several near-cancellations of the project, including a 2006 collapse of the publicprivate partnership intended to fund it. The project was revived in 2008, when it was decided that the EC would fund Galileo completely, using surplus money from the agriculture budget. Two test satellites for the system have been launched, in 2005 and 2008, although the latter was two years late.

Barroso told the conference that Europe can succeed in getting Galileo launched. "We must guarantee the success of our flagship programmes," he said. "Governance issues must not get in the way." Space policy will be further entrenched in EU policy if the Lisbon treaty is ratified as expected by January 2010; the treaty contains a provision stating that a pan-European space policy will be drawn up.

ESA developed Galileo and is contracted to procure services for it. This process is now

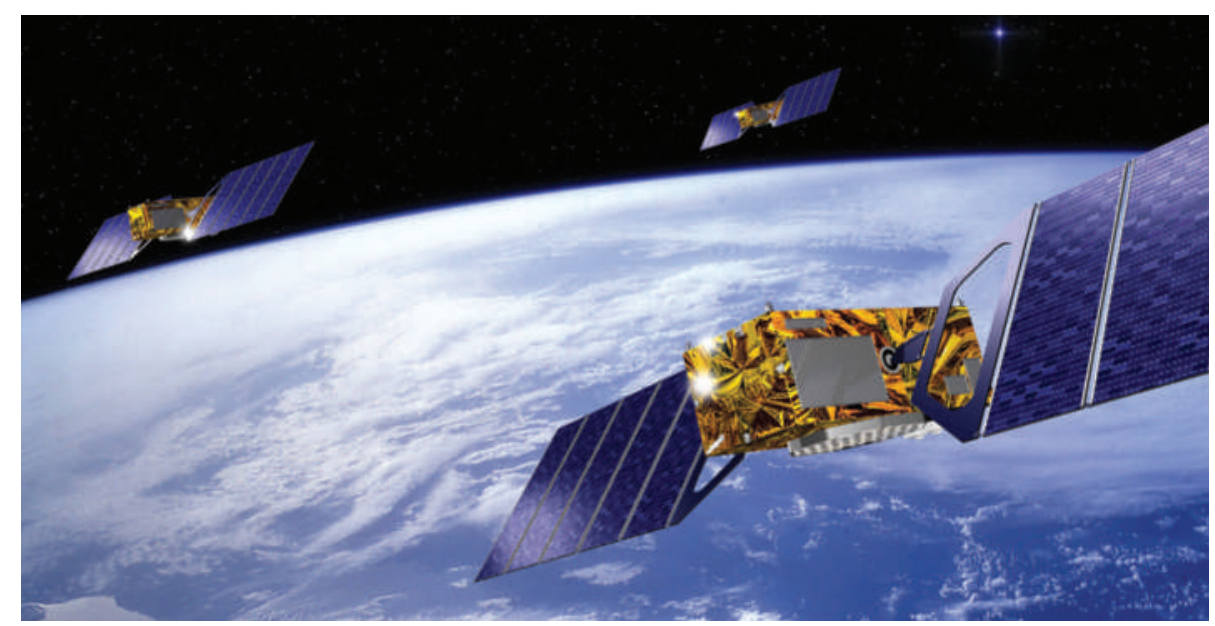

Europe plans to launch up to 30 satellites that will be independent of the US Global Positioning System.

in full swing, with a 13 November deadline for final tenders from companies bidding to provide satellites, integration systems and launches. "The plan is to sign the contracts as soon as possible," says Karamitsos.

The two leading contenders to build the bulk of the satellites for Galileo are EADS Astrium and a partnership between UK space company Surrey Satellite Technology, based in Guildford, and Germany's OHB. “There's a danger Europe will miss the boat," says Philip Davies of Surrey Satellite. "We're 10 years into the programme and still don't have working satellites."

The first four satellites are slated for launch by the end of next year, although this phase of the project has already overrun its budget by $€ 376$ million (US $\$ 560$ million). "In all space programmes there's always an overspend," argues Fotis Karamitsos, who directs the Galileo efforts for the EC's directorate-general for energy and transport. The money must come out of the overall €3.4-billion budget for Galileo and the related navigation system EGNOS (European Geostationary Navigation Overlay System), which became operational on 1 October.

The remaining 26 satellites are slated to begin launching at the end of 2012. But the current launch capacity is two satellites per launch, with a maximum of four launches per year from the Kourou site in French Guiana. That would mean that the maximum number of satellites in space by the end of 2013 would be only 14. An updated Ariane launcher capable of launching four satellites at a time might be ready by 2013, says René Oosterlinck, ESA's Galileo director.

While politicians discussed funding and launch details in Brussels, scientists gathered in Padua, Italy, last week to talk about what they can learn from Galileo.

Because both the GPS and Galileo emit signals that are reflected by Earth's surface, these signals can monitor long-term changes on the planet. "The biggest interest is that [scientists] have 40 or 50 satellites moving around, guaranteed, for years and years emitting signals," says Oosterlinck. Potential investigations, he says, could range from testing Einstein's theory of relativity to probing the ionosphere and troposphere. Each of the main satellites can also carry a small payload; around half of the satellites might be able to carry a small project for outside researchers, says Oosterlinck.

Meanwhile, Europe's GMES (Global Monitoring for Environment and Security)/ Kopernikus project might benefit from lessons learnt from Galileo's funding tribulations. Five families of satellites, known as Sentinels, are to be launched, beginning in 2012 . So far, $€ 1.6$ billion of the estimated $€ 2$.7-billion budget has been raised, including $€ 831$ million allocated at an EU ministerial meeting last November.

But without a better way to finance big projects over many years, Liebig says, GMES might fall prey to the same funding turbulence that has plagued Galileo.

Katharine Sanderson 